\title{
There is an association between sarcopenia, osteoporosis, and the risk of hip fracture
}

\author{
Sarkopeni, osteoporoz ve kalça kırığı riski arasında ilişki vardır \\ O. Şahap Atik, MD \\ Professor of Orthopedic Surgery, Turkish Joint Diseases Foundation, Ankara, Turkey
}

Sarcopenia is an age-related condition associated with progressive loss of muscle mass and function. It leads to physical disability, poor quality of life, and mortality. ${ }^{[1]}$ There is an association between sarcopenia, osteoporosis, and the risk of hip fracture; like distal radius fracture and hip fracture. ${ }^{[2,3]}$ Sarcopenia also increases the risk of five-year mortality in patients with osteoporotic hip fractures. ${ }^{[4]}$

Genetic, developmental, endocrine, and lifestyle factors, such as lack of physical activity, smoking, and poor diet have dual effects on both muscle and bone mass. ${ }^{[5]}$ Vitamin D receptor might be a key element of osteoporosis-sarcopenia connection in muscle atrophy of elderly patients. ${ }^{[6]}$

Due to low physical performance and high bone turnover, older adults with osteosarcopenia have to be regarded as the most at-risk population for fractures and disability. ${ }^{[7]}$ Interventions such as resistance training, optimal dietary protein, vitamin $\mathrm{D}$, and calcium intake have positive effect on bone and muscle, reducing falls, fractures, and, consequently, disability. ${ }^{[8]}$ A recent systematic review provides evidence of the beneficial effect of dairy protein to improve muscle mass in middle-aged and older adults. ${ }^{[9]}$

\section{REFERENCES}

1. Rodríguez-Rejón AI, Ruiz-López MD, Wanden-Berghe C, Artacho R. Prevalence and diagnosis of sarcopenia in residential facilities: A systematic review. Adv Nutr 2019;10:51-8.

2. Oliveira A, Vaz C. The role of sarcopenia in the risk of osteoporotic hip fracture. Clin Rheumatol 2015;34:1673-80.

3. Bozkurt HH, Atik OŞ, Tokgöz MA. Can distal radius or vertebra fractures due to low-energy trauma be a harbinger of a hip fracture? Eklem Hastalik Cerrahisi 2018;29:100-3.

4. Kim YK, Yi SR, Lee YH, Kwon J, Jang SI, Park SH. Effect of sarcopenia on postoperative mortality in osteoporotic hip fracture patients. J Bone Metab 2018;25:227-33.

5. Curtis E, Litwic A, Cooper C, Dennison E. Determinants of muscle and bone aging. J Cell Physiol 2015;230:2618-25.

6. Scimeca M, Centofanti F, Celi M, Gasbarra E, Novelli G, Botta A, et al. Vitamin D receptor in muscle atrophy of elderly patients: a key element of osteoporosis-sarcopenia connection. Aging Dis 2018;9:952-64.

7. Drey M, Sieber CC, Bertsch T, Bauer JM, Schmidmaier R. Osteosarcopenia is more than sarcopenia and osteopenia alone. Aging Clin Exp Res 2016;28:895-9.

8. Hirschfeld HP, Kinsella R, Duque G. Osteosarcopenia: where bone, muscle, and fat collide. Osteoporos Int 2017;28:2781-90.

9. Hanach NI, McCullough F, Avery A. The impact of dairy protein intake on muscle mass, muscle strength, and physical performance in middle-aged to older adults with or without existing sarcopenia: A systematic review and meta-analysis. Adv Nutr 2019;10:59-69. 